\title{
Effect of Polymer Coat, Seed Treatment Chemicals and Containers on Seed Germination, Vigour Index, Infestation and Other Quality Traits in Sweet Corn during Seed Storage
}

\author{
R. B. Jolli ${ }^{*}$, V. H. Nayak ${ }^{2}$, M. B. Boranayaka ${ }^{3}$ and H. C. Latha \\ (Seed Science \& Technology), RARS, Vijayapur, UAS Dharwad, Karnataka, India \\ (Plant Breeding), RARS, Vijayapur, UAS Dharwad, Karnataka, India \\ (Plant Breeding), AICSIP, RARS, Vijayapur, UAS Dharwad, Karnataka, India \\ (Entomology), AICSIP, RARS, Vijayapur, UAS Dharwad, Karnataka, India \\ *Corresponding author
}

\begin{abstract}
A B S T R A C T
Sweet corn (Zea mays L. spp. saccharata) also known as sugar corn is a hybridized variety of maize (Zea mays L.) specifically bred to increase the sugar content. The information on storage of sweet

Keywords

Sweet corn, Polymer coat, Seed quality, Vigour, Storage

Article Info

Accepted:

21 May 2020

Available Online:

10 June 2020

corn seeds to preserve viability and vigour from harvest to next planting season is of prime importance in any seed production programme. Certain seed treatments and storage containers are known to influence the storability of seeds in several crops. Hence, the laboratory experiment was conducted from 2017-2018 at Regional Agricultural Research Station, Hitnalli Farm, Vijayapur to ascertain the effect of polymer coat, seed treatment chemicals and containers on sweet corn seed quality during seed storage. The experiment was carried out in two factorial two factorial design. First factor consisted of eight treatments and second factor consisted of two containers viz., cloth bag and polythene bag. The results of investigation revealed that seeds stored in HDPE (polythene) bag showed better storability as compared to the cloth bag. At the end of nine months of storage period, seeds treated with polymer seed coating @ $10 \mathrm{ml} / \mathrm{kg}$ of seed + deltametrin $2.8 \mathrm{EC} @ 0.4 \mathrm{ml} / \mathrm{kg}$ seed + bavistin 50\% WP @ 2g/kg and seeds stored in polythene bag recorded significantly higher seed germination $(89.00 \%)$, shoot length $(17.81 \mathrm{~cm})$, root length $(19.58 \mathrm{~cm})$, seedling vigour index (3390), ten seedling dry weight (2.36 g), 100 seed weight $(10.81 \mathrm{~g})$ and lower EC value $\left(0.341 \mathrm{dSm}^{-1}\right)$ as compared to control. The moisture content, seed infection and insect infestation were least in the seeds stored in polythene bags compared to the seeds stored in cloth bags.
\end{abstract}

\section{Introduction}

Sweet corn is a perishable product that has to be delivered onto the market in the form of fresh cobs, or to processing plants in the form of corn kernels for canned or frozen food. Seed is a basic and vital input for sustained growth in agricultural productivity and production since ninety percent of the food crops are grown from seed (Schwinn, 1994). Seeds also require seed treatment for enclosing the protective chemicals, and nutrients added to the seeds without significant increase in the seed size or weight.

Polymer coating enables accurate and even dosage of chemicals and reduces the chemical wastage. The polymer coat also provides 
protection from the stress imposed by accelerated ageing, fungal infection and pest infestation. It improves emergence of seedlings and plant stand in the field. Accurate application of polymer coat helps to make room for including all required ingredients, protectants, nutrients, plant growth promoters, hydrophobic / hydrophilic substances, oxygen suppliers etc by encasing the seed within a thin film of biodegradable polymer and adherence of seed treatment chemicals to the seed ensures dust free handling and make treated seed both useful and environment friendly. Polymer coating makes sowing operation easier due to the smooth flow of seeds. Addition of colorant helps in visual monitoring of placement accuracy enhances the appearance, marketability and consumer preference. The polymer film coat may act as a physical barrier, which has been reported to reduce the leaching of inhibitors from the seed coverings and may restrict oxygen diffusion to the embryo (Vanangamudi et al., 2003).

Good storage is a basic requirement in seed production program as the maintenance of high seed viability and vigour from the harvest to planting is of utmost important in a seed production program. In storage, the seeds are to be protected against the pests and pathogens. The seeds can be treated with different fungicides to prevent the growth of micro-organisms and insect infestation. Seed treatments with fungicides not only controls seed-borne diseases but also improve seed heath, plant stand, germination and crop yield (Tanweer, 1982). The detailed information on these aspects of sweet corn is lacking and thus deserves the attention of understanding the above aspects that would be of much practical significance to improve the seed production. Hence, an investigation was carried out to know effect of polymer coat, seed treatment chemicals and containers on sweet corn seed quality during seed storage.

\section{Materials and Methods}

The fresh seeds of sweet corn variety (Madhuri) were obtained from MARS, UAS Dharwad for the storability studies. The laboratory experiment was conducted at RARS, Vijayapur during kharif 2017-18 with eight seed treatments ( $\mathrm{T}$ ) viz., $\mathrm{T}_{1-}$ (control), $\mathrm{T}_{2^{-}}$ (polymer seed coating@ $10 \mathrm{ml} / \mathrm{kg}$ of seed), $\mathrm{T}_{3}$-(Bavistin (carbendazim) 50\% WP @ 2g/kg seed), $\mathrm{T}_{4}$-(deltametrin 2.8EC @ $0.4 \mathrm{ml} / \mathrm{kg}$ seed), $\mathrm{T}_{5}$-(polymer seed coating @ $10 \mathrm{ml} / \mathrm{kg}$ of seed + bavistin (carbendazim) 50\% WP @2g/kg seed), T 6 -(polymer seed coating@ $10 \mathrm{ml} / \mathrm{kg}$ of seed + deltametrin 2.8EC @ $0.4 \mathrm{ml} / \mathrm{kg}$ seed), $\mathrm{T}_{7}$-(polymer seed coating @ $10 \mathrm{ml} / \mathrm{kg}$ of seed + deltametrin 2.8EC @ $0.4 \mathrm{ml} / \mathrm{kg}$ seed + bavistin (carbendazim) $50 \%$ WP @ 2g/kg seed), T8-(deltametrin 2.8EC @ $0.4 \mathrm{ml} / \mathrm{kg}$ seed + bavistin (carbendazim) $50 \%$ WP @ $2 \mathrm{~g} / \mathrm{kg}$ seed) and two containers viz., cloth bag $\left(\mathrm{C}_{1}\right)$ and polythene bag $\left(\mathrm{C}_{2}\right)$.

The seed samples were treated as per the treatments and packed in containers and stored under ambient storage conditions for nine months. The seed samples were drawn at monthly intervals for determining the seed quality parameters viz., germination, root length, shoot length, vigour index, seedling dry weight, hundred seed weight, electrical conductivity of seed leachate, moisture content and seed health.

\section{Statistical analysis}

The data collected from the experiment was analyzed statistically by adopting the procedures as described by Sundarajan et al., (1972) and critical differences were calculated at one per cent level, wherever, ' $F$ ' test was significant. The data on germination percentage was transformed into Arc sine square root percentage values (Snedecor and Cochran, 1967). 


\section{Results and Discussion}

Sweet corn seeds were treated with insecticide, fungicides and polymer coating exhibited superiority in maintaining the seed quality throughout the storage period. The seeds treated with Polymer seed coating @ 10 $\mathrm{ml} / \mathrm{kg}$ of seed in combination with deltametrin $2.8 \mathrm{EC} @ 0.4 \mathrm{ml} / \mathrm{kg}$ seed and bavistin (carbendazim) 50\% WP @ 2g/kg seeds recorded significantly higher seed quality parameters followed by the seeds treated with polymer seed coating @ $10 \mathrm{ml} / \mathrm{kg}$ of seed in combination with bavistin (carbendazim) 50\% WP @ $2 \mathrm{~g} / \mathrm{kg}$ seed which were on par with each other in most of the seed quality parameters compared to the untreated control.

The germination percentage of sweet corn seeds declined progressively with the increase in the period of storage in all the treatment combinations, which may be attributed to the phenomenon of natural ageing and depletion of food reserves and decline in metabolic activity of seed due to respiration. There was a significant difference on germination per cent from the third month onwards of storage period and up to the end of nine months of storage (Table 1a \& 1b). The germination was significantly higher $(89.68 \%)$ in the seeds treated with polymer seed coating @ $10 \mathrm{ml} / \mathrm{kg}$ of seed + deltametrin 2.8EC @ $0.4 \mathrm{ml} / \mathrm{kg}$ seed + bavistin (carbendazim) 50\% WP @ 2g/kg seeds, and 88.53 per cent germination in polymer seed coating @ $10 \mathrm{ml} / \mathrm{kg}$ of seed + bavistin (carbendazim) 50\% WP @ $2 \mathrm{~g} / \mathrm{kg}$ seed. On the contrary, significantly lower germination $(83.95 \%)$ was noticed in the untreated seeds at the end of storage period. Higher germination percentage can be seen in the treated seeds and it may be due to pathogen and pest suppressive nature of chemicals. In general, Bavistin (carbendazim) reduces the impact of ageing enzymes, seed deterioration due to fungal invasion and physiological ageing. Deltamethrin is a pyrithroid and it was very effective in controlling the insect pest during storage due to the phytotoxic effect. Further polymer film acted as physical barrier, which has been reported to reduce the leaching of inhibitors from the seed coverings and may restrict oxygen diffusion to embryo. So, the seed viability was maintained for comparatively longer period of time. These finding are in agreement with the results obtained by Shakuntala (2009) in sunflower; Imran Baig (2005) in soybean; Vinodkumar et al., (2012) in pigeonpea and Sushma (2013) in bengal gram.

At the end of nine months of storage period, significantly higher shoot length $(17.27 \mathrm{~cm})$ and root length $(18.9 \mathrm{~cm})$ was recorded in the seeds treated with polymer seed coating @ 10 $\mathrm{ml} / \mathrm{kg}$ of seed in combination with deltametrin $2.8 \mathrm{EC} @ 0.4 \mathrm{ml} / \mathrm{kg}$ seed and bavistin (carbendazim) 50\% WP @ 2g/kg seeds $\left(\mathrm{T}_{7}\right)$ followed by treatment $\mathrm{T}_{5}$ where in the seeds were treated with the combination of polymer seed coating @ $10 \mathrm{ml} / \mathrm{kg}$ of seed and bavistin (carbendazim) 50\% WP @2g/kg seed which recorded the of shoot length $(17.05 \mathrm{~cm})$ and root length of $(18.63 \mathrm{~cm})$. Significantly lower shoot length $(14.69 \mathrm{~cm})$ and root length $(15.91 \mathrm{~cm})$ was observed in the untreated seeds. The shoot length and root length of polymer coated seeds with insecticide and fungicide were more as compared to the uncoated seeds. It is due to higher germination and healthy seedlings in seeds coated with polymer, insecticide and fungicide as this protected the seeds from fungi and insect invasion of seeds and there by good and better germination and subsequent higher root and shoot length was produced. Similar results were reported by Shakuntala (2009) in sunflower; Imran Baig (2005) in soybean and Poonam Singh et al., (2004) in rice. Due to elongation of shoot due to proper supply of water and nutrients which were enabled by the polymers. 
In the present study, significantly higher vigour index was recorded in treatment $T_{7}$ wherein the the seeds were treated with polymer seed coating @ $10 \mathrm{ml} / \mathrm{kg}$ of seed in combination of deltametrin 2.8EC @ $0.4 \mathrm{ml} / \mathrm{kg}$ seed and bavistin (carbendazim) $50 \%$ WP @ 2g/kg seeds (3261) and was on par with the seeds treated with polymer seed coating@10 ml/kg of seed in combination of bavistin (carbendazim) 50\% WP @2g/kg seed (3187) $\mathrm{T}_{5}$ and seeds treated with deltametrin $2.8 \mathrm{EC} @ 0.4 \mathrm{ml} / \mathrm{kg}$ seed and bavistin (carbendazim) 50\% WP @ 2g/kg seed (3111) $\mathrm{T}_{8}$. While, significantly lower vigour index (2735) was recorded in the untreated seeds at the end of storage period (Table $2 \mathrm{a} \& 2 \mathrm{~b}$ ). The decrease in vigour index may be due to age induced decline in germination, decrease in root and shoot length and seedling dry weight and higher electrical conductivity of seed leachate. Higher vigour index in polymer coating along with fungicide and insecticide is due to more germination coupled with root and shoot length, seedling dry weight, lesser infection by storage fungi and very low infestation of insects. Similar findings were reported by Savitri et al., (1994) in sorghum; Savitri et al., (1998) in groundnut and Suresh and Renganayaki (2008) in maize seeds.

Dry weight of seedling decreased with increase in the storage period. This may be due to natural ageing, which may be resulted due to deterioration of seed, decrease in the germination percentage and seedling length. Among the treatment combinations, the seeds treated with polymer seed coating @ $10 \mathrm{ml} / \mathrm{kg}$ of seed in combination of deltametrin $2.8 \mathrm{EC}$ @ $0.4 \mathrm{ml} / \mathrm{kg}$ seed and bavistin (carbendazim) $50 \% \quad W P @ 2 \mathrm{~g} / \mathrm{kg}$ seeds $\mathrm{T}_{7}$ recorded significantly highest seedling dry weight $(2.27 \mathrm{~g})$ followed by the seeds treated with polymer seed coating @ $10 \mathrm{ml} / \mathrm{kg}$ of seed in combination with bavistin (carbendazim) 50\% WP @ $2 \mathrm{~g} / \mathrm{kg}$ seed (2.02 g) $\mathrm{T}_{5}$. While, significantly lowest seedling dry weight was recorded in the (untreated) as $1.05 \mathrm{~g}$ noticed at the end of nine months of storage period. These results are in conformity with the findings of Paul et al., (1996) in mungbean; Imran Baig (2005) in soybean; Shakuntala (2009) in sunflower and Hunje et al., (1990) in cowpea seeds.

Hundred seed weight of treated seeds showed significant variation from fourth month to till the end of nine months. Significantly higher hundred seed weight (10.64 g) was recorded in seeds treated with combination of polymer seed coating@10 ml $/ \mathrm{kg}$ of seed, deltametrin $2.8 \mathrm{EC} @ 0.4 \mathrm{ml} / \mathrm{kg}$ seed and bavistin (carbendazim) 50\% WP @ 2g/kg seeds $\mathrm{T}_{7}$ and was on par with the seeds treated with combination of polymer seed coating @ 10 $\mathrm{ml} / \mathrm{kg}$ of seed and bavistin (carbendazim) $50 \%$ WP @2g/kg seed (10.43 g) $\mathrm{T}_{5}$. While, significantly lower hundred seed weight $(9.24$ g) was recorded in untreated seeds. The decrease in the hundred seed weight was observed as the storage period increased. This may be due to fluctuation of seed moisture content during storage, infestation of the insects, which will feed both internally and externally and also due to activity of the fungi. These results are similar to the findings of Hussaini et al., (1988) in maize seeds.

A number of water soluble compounds such as sugars, amino acids and organic acids are released when the seeds were soaked in water. The electrical conductivity of seed leachate indicates the membrane integrity and quality of seed and it was negatively correlated with the seed quality. In the present investigation significantly lower mean electrical conductivity $\left(0.341 \mathrm{dSm}^{-1}\right)$ was recorded in the seeds treated with combination of polymer seed coating @ $10 \mathrm{ml} / \mathrm{kg}$ of seed + deltametrin 2.8EC @ 0.4ml $/ \mathrm{kg}$ seed + bavistin (carbendazim) 50\% WP @ 2g/kg seeds $\mathrm{T}_{7}$ followed by the seeds treated with combination of polymer seed coating @ 10 
$\mathrm{ml} / \mathrm{kg}$ of seed + bavistin (carbendazim) $50 \%$ WP @2g/kg seed $\left(0.356 \mathrm{dSm}^{-1}\right) \mathrm{T}_{5}$. While, significantly higher electrical conductivity of seed leachate $\left(0.534 \mathrm{dSm}^{-1}\right)$ was recorded in the untreated seeds at the end of storage period. This variation in electrical conductivity of seed leachate indicated that increased membrane permeability and decreased compactness of seed coat and cellular membrane deterioration. Similar, findings were reported by Vasundhara and Bommegowda (1999) in groundnut; Vinodkumar (2012) in pigeonpea; Patil et al., (2004) in pearl millet and Sushma (2003) in garden pea. The polymer film formed around seed acted a physical barrier, which has been reported to reduce leaching of inhibitors from seed covering and may restrict oxygen diffusion in to the embryo (Vanangamudi et al., 2003). The stable cell membrane also rendered resistance to peroxidase and free radical reactions and bavistin (carbendazim) acted as antifungal and anti oxidant agent.

There was no significant difference in the moisture content due to seed polymer coating insecticide and fungicide up to the end of storage period. The results of the present study revealed that the moisture content of the seeds increased with increase in the period of storage. It ranged from 8.33 per cent at the beginning of storage to 9.24 per cent at the end of eight months after storage. Increase in the seed moisture might be due to metabolic release of water during respiration and the hygroscopic nature of seed. Seed health status of seed also might be one of the reasons for increasing moisture content in hydro-primed seeds. These results are in agreement with the findings of Roberts and Abdulla (1986) in barly, broad bean and peas.

Seed health is a major consideration in any seed production programme next to vigour and viability of seeds. Seed health is always associated with seed quality. Healthy seeds must be free from both insect infestation and pathogen infection. The fungal infection increased with the advancement of storage period. The seed infection may be due to seed polymer coating, insecticide and fungicide varied significantly after four months of storage period. The seeds treated with polymer seed coating@10 ml + deltametrin 2.8 EC@0.4ml + bavistin (carbendazim) $50 \%$ WP @ 2g/kg seed $\mathrm{T}_{7}$ recorded the lowest $(0.16$ and $1.21 \%)$ followed by deltametrin 2.8 EC @ $0.4 \mathrm{ml} / \mathrm{kg}+$ bavistin (carbendazim) 50\% WP @ 2g per kg seed $(0.22$ and $1.49 \%) \mathrm{T}_{8}$ and the seeds treated with combination of polymer seed coating @ $10 \mathrm{ml} / \mathrm{kg}$ of seed + bavistin (carbendazim) 50\% WP @ 2g/kg seed (0.31 and $1.47 \%) \mathrm{T}_{5}$.

Seed infection was highest in control (0.99 and $3.05 \%$ ) at the fourth and nine months of storage period, respectively. The fungal pathogens namely, Aspergillus flavus, Aspergillus niger, Penicillium spp., Fusarium moniliforme and Rhizopus spp. were found on sweet corn seeds predominantly during storage and the infection was more in uncoated seeds. It might be due to increased moisture absorption by the seeds and the seed without plant protection chemicals. Lower percentage of infection in the coated seed might be due to the toxic effect of coating fungicide on pathogen, in spite of its higher moisture absorption.

Hence, the deterioration of treated seed was less compared to the untreated seeds. Similar reports were reported by Ravishankar et al., (2002) in maize and sorghum; Manojkumar and Agarwal (1998) in which seeds treated with thiram effectively controlled the seed borne disease in maize; Paul and Mishra, 1994 in maize reported that mycelial growth was significantly less for the polymer coated soybean seeds at every observation period and the polymer coat itself provided protection from the fungi invasion. 
Hunje (2002) reported that stable cell membrane rendered resistance to peroxidase and free radical reactions and thiram acted as antifungal agent.

The seed infestation due to the treatment of seed polymer coating, fungicide and insecticide varied significantly after two months of storage period (Table $3 a \& 3 b$ ). Significantly lower insect infestation was recorded in the seeds treated with deltametrin $2.8 \mathrm{EC} @ 0.4 \mathrm{ml} / \mathrm{kg}$ seed $(0.00$ and $0.61 \%) \mathrm{T}_{4}$ followed by deltametrin 2.8EC @ $0.4 \mathrm{ml} / \mathrm{kg}$ seed + bavistin (carbendazim) 50\% WP @ $2 \mathrm{~g} / \mathrm{kg}$ seed $(0.00$ and $0.79 \%) \quad \mathrm{T}_{8}$ and polymer seed coating @ $10 \mathrm{ml} / \mathrm{kg}$ of seed + bavistin (carbendazim) 50\% WP @2g/kg seed $\mathrm{T}_{5}$ was less $(0.00$ and $0.80 \%)$. It was highest in control (0.16 and $5.02 \%)$ at the second and nine months of storage period, respectively. There was no insect infestation in the seeds treated with the combination of polymer coat, insecticide and fungicide. Seeds coated with liquid polymer created smooth surface on seed coat so there is no choice to lay eggs on seed coat apart from that deltamethrin is a pyrithroid which is very effective in controlling the insect pest during storage due to phytotoxic effect. Similar results were reported by Vijaykumar et al., (2007) in cotton; Vinodkumar et al., (2012) in pigeonpea and Sushma (2013) in bengal gram seeds.

\section{Effect of containers on sweet corn seed quality during storage}

The most important factors that determine the longevity of seed in storage are moisture content of seed, temperature and relative humidity. As the seed being hygroscopic in nature, it exhibited fluctuation in seed moisture content due to change in atmospheric relative humidity and temperature. Use of sealed container has also been reported to maintain seed viability and vigour (Roberts and Abdalla, 1986). The cereal seeds are packed in cloth or gunny bags, both of these containers are permeable to moisture. So, it is essential to preserve the seeds in suitable moisture proof containers, which eliminate dampness, deterioration and micro organism, thereby enhancing the seed longevity or seed storability.

This investigation was carried out with a view to study the storage behaviour of sweet corn seeds in moisture pervious and moisture impervious containers and was kept in ambient condition, which aimed at developing low cost input methods suitable under resource limitation. In the present study, the results of germination percentage, moisture content, root length and shoot length, seedling dry weight, vigour index, hundred seed weight, seed health status and electrical conductivity of seed leachate as influenced by containers are discussed here under. Containers did significantly influence on germination, moisture content, root length and shoot length, seedling dry weight, vigour index, hundred seed weight, seed health status and electrical conductivity of seed leachate. Quality of seeds in terms of above mentioned parameters were high in polythene bag as compared to cloth bag at the end of eight months of storage except seed health status and electrical conductivity of seed leachate.

Germination was higher with the seeds stored in polythene bag (87.98\%) and lowest $(85.21 \%)$ in the cloth bag at the end of nine months of storage period. The superiority of 700 gauge polythene bag in storage was recorded as compared to the cloth bag. Polythene bag which is moisture resistant experienced relatively low fluctuation in seed moisture as compared to the seeds stored in moisture pervious containers i.e. in cloth bag. These results are in conformity with the findings of Zink and DcMendonca (1965) in pumpkin and Martin et al., (1960) in okra. 
Germination rate of soybean seeds varied widely due to different moisture content of different containers. It was observed that germination rate was almost similar at initial stage but it decreased with increase of storage period. After storage the germination rate was better in seeds of tin (87.34\%) and polythene bag $(84.73 \%)$ compared to that of cloth bag (68.51\%) (Monira et al., 2012). The shoot length, root length, seedling dry weight and hundred seed weight of sweet corn seeds decreased gradually with the advancement in storage period. Significant difference was observed in the above parameters due to containers. Higher shoot length, root length, seedling dry weight and hundred seed weight $(16.65 \mathrm{~cm}, 18.34 \mathrm{~cm}, 1.78 \mathrm{~g}$ and $10.24 \mathrm{~g}$, respectively) were noticed in the seeds stored in the polythene bag as compared to the cloth bag which recorded lower speed of germination, lower shoot length $(15.64 \mathrm{~cm})$, root length $(17.04 \mathrm{~cm})$, seedling dry weight $(1.50 \mathrm{~g})$ and hundred seed weight $(9.55 \mathrm{~g})$. It is concluded that maintenance of vigour and viability was consistent in 700 gauge polythene bag as compared to the cloth bag due to less fluctuation in extrinsic factors such as relative humidity, temperature. These results are in conformity with the findings of Riudavets et al., (2007) and Sunilkumar et al., (2005) in sorghum and Merwade (2000) in chick pea.

Containers significantly influence the vigor throughout the storage period. Higher vigour index (3139) was recorded in seeds stored in polythene bag as compared to cloth bag which recorded lower vigour index (2891) at the end of nine months of storage period. The vigour index decreased with increase in the storage period due to decrease in germination, shoot and root length and seedling dry weight. Containers also have significantly influence on the moisture content, electrical conductivity of seed leachate and percent seed infection and infestation at the end of eight months of storage period. Lower electrical conductivity of seed leachate $\left(0.381 \mathrm{dSm}^{-1}\right)$, moisture content $(8.68 \%)$, per cent infection $(1.08 \%)$ and infestation (.99\%) were recorded in the seeds stored in polythene bag where as higher electrical conductivity of seed leachate, moisture content, percent, infection and infestation $\left(0.576 \mathrm{dSm}^{-1}, 9.80 \%, 2.28 \%\right.$ and $2.57 \%$, respectively) were recorded in the seeds stored in cloth bag at the end of eight months of storage. The moisture content, electrical conductivity of seed leachate, percent seed infection and infestation was increased with the increase in the storage period due to ageing of seeds and invasion by storage fungi. It is reported that polythene bag is more resistant to biotic and abiotic stresses. These results are in conformity with the findings of Zink and DcMendonca (1965) in pumpkin.

\section{Interaction effect}

Germination percentage, shoot length, root length, vigour index, seedling dry weight, and hundred seed weight, moisture content, quality of seed in terms of above mentioned parameters showed non-significant differences in the interaction effect between treatment and containers up to the end of storage period. The interaction effects of storage containers and seed treatments were found significant from fourth month of storage up to eighth month in electrical conductivity of seed leachate. Among interactions significantly maximum $(0.416$ $\mathrm{dSm}^{-1}$ ) electrical conductivity was recorded in $\mathrm{C}_{1} \mathrm{~T}_{1}$ (Untreated seeds stored in cloth bag) followed by $\mathrm{C}_{1} \mathrm{~T}_{4}$ (seeds treated with deltametrin 2.8EC @ $0.4 \mathrm{ml} / \mathrm{kg}$ seed and stored in cloth bag) $\left(0.404 \mathrm{dSm}^{-1}\right)$ and was minimum with $\mathrm{C}_{2} \mathrm{~T}_{7}$ (seeds treated with polymer seed coating @ $10 \mathrm{ml} / \mathrm{kg}$ of seed + deltametrin 2.8EC @ 0.4ml $/ \mathrm{kg}$ seed + bavistin (carbendazim) 50\% WP @ 2g/kg seed and stored in polythene bag) $\left(0.208 \mathrm{dSm}^{-1}\right)$. 
Table.1 Effect of polymer coating, chemical seed treatment and containers on seed germination percentage of sweet corn cv. Madhuri

\begin{tabular}{|c|c|c|c|c|c|c|c|c|c|c|c|c|c|c|c|}
\hline \multirow[t]{2}{*}{ Treatments } & \multicolumn{3}{|c|}{ Initial month } & \multicolumn{3}{|c|}{ First month } & \multicolumn{3}{|c|}{ Second month } & \multicolumn{3}{|c|}{ Third month } & \multicolumn{3}{|c|}{ Fourth month } \\
\hline & $\mathbf{C}_{1}$ & $\mathbf{C}_{2}$ & Mean & $\mathbf{C}_{1}$ & $\mathrm{C}_{2}$ & Mean & $\mathrm{C}_{1}$ & $\mathbf{C}_{2}$ & Mean & $\mathbf{C}_{1}$ & $\mathrm{C}_{2}$ & Mean & $\mathbf{C}_{1}$ & $\mathbf{C}_{2}$ & Mean \\
\hline $\mathbf{T}_{1}$ & $\begin{array}{c}98.10 \\
(82.30)^{*}\end{array}$ & $\begin{array}{c}98.23 \\
(82.56)\end{array}$ & $\begin{array}{c}98.17 \\
(82.43)\end{array}$ & $\begin{array}{c}98.10 \\
(82.29)\end{array}$ & $\begin{array}{c}98.31 \\
(82.64)\end{array}$ & $\begin{array}{c}98.21 \\
(82.46)\end{array}$ & $\begin{array}{c}95.38 \\
(77.63)\end{array}$ & $\begin{array}{c}97.13 \\
(80.45)\end{array}$ & $\begin{array}{c}96.26 \\
(79.04)\end{array}$ & $\begin{array}{c}93.96 \\
(75.83)\end{array}$ & $\begin{array}{c}95.10 \\
(77.29)\end{array}$ & $\begin{array}{c}94.53 \\
(76.56)\end{array}$ & $\begin{array}{c}93.11 \\
(74.88)\end{array}$ & $\begin{array}{c}94.28 \\
(76.21)\end{array}$ & $\begin{array}{c}93.70 \\
(\mathbf{7 5 . 5 2})\end{array}$ \\
\hline $\mathbf{T}_{2}$ & $\begin{array}{c}98.34 \\
(82.64)\end{array}$ & $\begin{array}{c}98.50 \\
(83.44)\end{array}$ & $\begin{array}{c}98.42 \\
(83.04)\end{array}$ & $\begin{array}{c}98.15 \\
(82.35)\end{array}$ & $\begin{array}{c}98.34 \\
(82.70)\end{array}$ & $\begin{array}{c}98.25 \\
(82.53)\end{array}$ & $\begin{array}{c}96.86 \\
(79.83)\end{array}$ & $\begin{array}{c}97.75 \\
(81.44)\end{array}$ & $\begin{array}{c}97.31 \\
(80.64)\end{array}$ & $\begin{array}{c}95.00 \\
(77.19)\end{array}$ & $\begin{array}{c}95.88 \\
(78.37)\end{array}$ & $\begin{array}{c}95.44 \\
(77.78)\end{array}$ & $\begin{array}{c}94.06 \\
(75.94)\end{array}$ & $\begin{array}{c}95.21 \\
(78.66)\end{array}$ & $\begin{array}{c}94.64 \\
(76.67)\end{array}$ \\
\hline $\mathbf{T}_{3}$ & $\begin{array}{c}98.50 \\
(83.19)\end{array}$ & $\begin{array}{c}99.26 \\
(85.17)\end{array}$ & $\begin{array}{c}98.88 \\
(84.18)\end{array}$ & $\begin{array}{c}98.50 \\
(83.22)\end{array}$ & $\begin{array}{c}99.10 \\
(84.73)\end{array}$ & $\begin{array}{c}98.80 \\
(83.97)\end{array}$ & $\begin{array}{c}97.00 \\
(81.36)\end{array}$ & $\begin{array}{c}98.10 \\
(82.24)\end{array}$ & $\begin{array}{c}97.55 \\
(81.80)\end{array}$ & $\begin{array}{c}96.08 \\
(78.63)\end{array}$ & $\begin{array}{c}96.53 \\
(79.32)\end{array}$ & $\begin{array}{c}96.31 \\
(78.98)\end{array}$ & $\begin{array}{c}94.87 \\
(76.94)\end{array}$ & $\begin{array}{c}96.10 \\
(77.53)\end{array}$ & $\begin{array}{c}95.48 \\
(77.80)\end{array}$ \\
\hline $\mathbf{T}_{4}$ & $\begin{array}{c}98.25 \\
(82.50)\end{array}$ & $\begin{array}{c}98.75 \\
(83.75)\end{array}$ & $\begin{array}{c}\text { 98.50 } \\
(\mathbf{8 3 . 1 3})\end{array}$ & $\begin{array}{c}98.40 \\
(82.26)\end{array}$ & $\begin{array}{c}98.75 \\
(83.73)\end{array}$ & $\begin{array}{c}98.58 \\
(83.29)\end{array}$ & $\begin{array}{c}96.34 \\
(79.10)\end{array}$ & $\begin{array}{c}98.00 \\
(82.07)\end{array}$ & $\begin{array}{c}97.17 \\
(\mathbf{8 0 . 5 8})\end{array}$ & $\begin{array}{c}94.86 \\
(76.94)\end{array}$ & $\begin{array}{l}95.86( \\
78.33)\end{array}$ & $\begin{array}{c}95.36 \\
(77.63)\end{array}$ & $\begin{array}{c}93.86 \\
(75.70)\end{array}$ & $\begin{array}{c}95.29 \\
(78.57)\end{array}$ & $\begin{array}{c}94.57 \\
(76.61)\end{array}$ \\
\hline $\mathbf{T}_{5}$ & $\begin{array}{c}99.10 \\
(84.71)\end{array}$ & $\begin{array}{c}99.20 \\
(84.96)\end{array}$ & $\begin{array}{c}99.15 \\
(84.83)\end{array}$ & $\begin{array}{c}99.00 \\
(84.46)\end{array}$ & $\begin{array}{c}99.45 \\
(85.97)\end{array}$ & $\begin{array}{c}99.23 \\
(85.22)\end{array}$ & $\begin{array}{c}97.60 \\
(81.15)\end{array}$ & $\begin{array}{c}98.45 \\
(83.06)\end{array}$ & $\begin{array}{c}98.03 \\
(82.10)\end{array}$ & $\begin{array}{c}96.14 \\
(78.76)\end{array}$ & $\begin{array}{c}97.47 \\
(81.15)\end{array}$ & $\begin{array}{c}96.81 \\
(79.96)\end{array}$ & $\begin{array}{c}95.37 \\
(77.66)\end{array}$ & $\begin{array}{c}96.03 \\
(78.57)\end{array}$ & $\begin{array}{c}95.70 \\
(\mathbf{7 8 . 1 1})\end{array}$ \\
\hline $\mathbf{T}_{6}$ & $\begin{array}{c}98.68 \\
(83.51)\end{array}$ & $\begin{array}{c}98.75 \\
(83.67)\end{array}$ & $\begin{array}{c}98.72 \\
(\mathbf{8 3 . 5 9})\end{array}$ & $\begin{array}{c}98.75 \\
(83.76)\end{array}$ & $\begin{array}{c}98.90 \\
(84.08)\end{array}$ & $\begin{array}{c}98.83 \\
(83.92)\end{array}$ & $\begin{array}{c}96.88 \\
(79.88)\end{array}$ & $\begin{array}{c}98.15 \\
(82.27)\end{array}$ & $\begin{array}{c}97.52 \\
(81.07)\end{array}$ & $\begin{array}{c}95.90 \\
(78.49)\end{array}$ & $\begin{array}{c}96.51 \\
(76.41)\end{array}$ & $\begin{array}{c}96.21 \\
(78.95)\end{array}$ & $\begin{array}{c}94.73 \\
(76.79)\end{array}$ & $\begin{array}{c}95.53 \\
(77.89)\end{array}$ & $\begin{array}{c}95.13 \\
(\mathbf{7 7 . 3 4})\end{array}$ \\
\hline $\mathbf{T}_{7}$ & $\begin{array}{c}99.26 \\
(85.19)\end{array}$ & $\begin{array}{c}99.30 \\
(85.36)\end{array}$ & $\begin{array}{c}99.28 \\
(85.27)\end{array}$ & $\begin{array}{c}99.15 \\
(84.82)\end{array}$ & $\begin{array}{c}99.07 \\
(84.51)\end{array}$ & $\begin{array}{c}99.11 \\
(84.66)\end{array}$ & $\begin{array}{c}97.90 \\
(81.73)\end{array}$ & $\begin{array}{c}98.56 \\
(83.22)\end{array}$ & $\begin{array}{c}98.23 \\
(82.47)\end{array}$ & $\begin{array}{c}96.90 \\
(79.97)\end{array}$ & $\begin{array}{c}97.79 \\
(81.53)\end{array}$ & $\begin{array}{c}97.34 \\
(\mathbf{8 0 . 7 5 )}\end{array}$ & $\begin{array}{c}95.78 \\
(78.19)\end{array}$ & $\begin{array}{c}96.53 \\
(79.32)\end{array}$ & $\begin{array}{c}96.15 \\
(78.75)\end{array}$ \\
\hline $\mathbf{T}_{8}$ & $\begin{array}{c}98.75 \\
(83.71)\end{array}$ & $\begin{array}{c}98.90 \\
(84.04)\end{array}$ & $\begin{array}{c}98.83 \\
(\mathbf{8 3 . 8 8})\end{array}$ & $\begin{array}{c}98.80 \\
(83.77)\end{array}$ & $\begin{array}{l}98.75 \\
(83.64)\end{array}$ & $\begin{array}{c}98.78 \\
(\mathbf{8 3 . 7 1})\end{array}$ & $\begin{array}{c}97.30 \\
(80.61)\end{array}$ & $\begin{array}{c}98.12 \\
(82.26)\end{array}$ & $\begin{array}{c}97.71 \\
(81.43)\end{array}$ & $\begin{array}{l}96.33 \\
(79.02\end{array}$ & $\begin{array}{c}96.62 \\
(79.59)\end{array}$ & $\begin{array}{c}96.48 \\
(79.31)\end{array}$ & $\begin{array}{c}95.06 \\
(77.20)\end{array}$ & $\begin{array}{l}95.25 \\
(77.61)\end{array}$ & $\begin{array}{c}95.15 \\
(77.40)\end{array}$ \\
\hline C=Mean & $\begin{array}{c}98.62 \\
(\mathbf{8 3 . 4 7})\end{array}$ & $\begin{array}{c}98.86 \\
(84.12)\end{array}$ & $\begin{array}{c}98.74 \\
(\mathbf{8 3 . 7 9})\end{array}$ & $\begin{array}{c}98.61 \\
(83.44)\end{array}$ & $\begin{array}{c}98.83 \\
(84.00)\end{array}$ & $\begin{array}{c}98.72 \\
(83.72)\end{array}$ & $\begin{array}{c}96.91 \\
(80.61)\end{array}$ & $\begin{array}{c}98.03 \\
(82.13)\end{array}$ & $\begin{array}{c}97.47 \\
(81.14)\end{array}$ & $\begin{array}{c}95.65 \\
(78.10)\end{array}$ & $\begin{array}{c}96.47 \\
(79.39)\end{array}$ & $\begin{array}{c}96.06 \\
(78.74)\end{array}$ & $\begin{array}{c}94.60 \\
(76.66)\end{array}$ & $\begin{array}{c}95.53 \\
(77.90)\end{array}$ & $\begin{array}{c}95.06 \\
(77.28)\end{array}$ \\
\hline & S.Em \pm & & $(\mathbf{P}=\mathbf{0 . 0 1})$ & S.Em & $=\quad$ CD & $(\mathrm{P}=0.01)$ & S.Em & : $\quad$ CD & $(\mathbf{P}=\mathbf{0 . 0 1})$ & S.Em & CD & $(\mathbf{P}=\mathbf{0 . 0 1})$ & S.Em \pm & & $(\mathbf{P}=\mathbf{0 . 0 1})$ \\
\hline Container (C) & 0.30 & & NS & 0.28 & & NS & 0.40 & & 1.51 & 0.31 & & 1.17 & 0.21 & & 0.79 \\
\hline Treatments (T) & 0.60 & & NS & 0.57 & & NS & 0.81 & & NS & 0.63 & & 2.33 & 0.42 & & 1.58 \\
\hline C XT & 0.85 & & NS & 0.80 & & NS & 1.14 & & NS & 0.88 & & NS & 0.60 & & NS \\
\hline $\begin{array}{l}\text { NS - Non significa } \\
\text { Containers (C) }\end{array}$ & $: \mathrm{C}_{1}-$ Cloth & & Figures in & he parenth & esis are arc & sine transf & rmed valu & & & & & & & & \\
\hline Treatments $(\mathrm{T})$ & & & & & & & & & & & & & & & \\
\hline $\mathrm{T}_{1}$-Control & & & & $\mathrm{T}_{5^{-}}$Poly & mer seed cc & oating @ 1 & $0 \mathrm{ml} / \mathrm{kg}$ of & seed $+\mathrm{Ba}$ & istin (carb & endazim) 5 & \% WP @ & $2 \mathrm{~g} / \mathrm{kg}$ seed & & & \\
\hline $\mathrm{T}_{2}$ - Polymer seed cc & ting@10m & $\mathrm{nl} / \mathrm{kg}$ of $\mathrm{se}$ & & $\mathrm{T}_{6}$ - Poly & mer seed c & oating @ 1 & $0 \mathrm{ml} / \mathrm{kg}$ of & seed + Del & tametrin 2 & 8EC@0.4 & $\mathrm{ml} / \mathrm{kg} \mathrm{seec}$ & & & & \\
\hline $\begin{array}{l}\mathrm{T}_{3}-\text { Bavistin (carbe } \\
\text { seed }\end{array}$ & Idazim) $50 \%$ & b WP@ & $2 \mathrm{~g} / \mathrm{kg}$ & $\begin{array}{l}\mathrm{T}_{7-} \text { Poly } \\
+ \text { Bavist }\end{array}$ & $\begin{array}{l}\text { mer seed c } \\
\text { in (carbend }\end{array}$ & $\begin{array}{l}\text { oating @ } 1 \\
\text { azim) 50\% }\end{array}$ & $\begin{array}{l}0 \mathrm{ml} / \mathrm{kg} \text { of } \\
\mathrm{WP} @ 2 \mathrm{~g}\end{array}$ & $\begin{array}{l}\text { seed }+ \text { Del } \\
\text { kg seed }\end{array}$ & tametrin 2 & 8EC@ 0.4 & $\mathrm{ml} / \mathrm{kg} \mathrm{seec}$ & & & & \\
\hline $\mathrm{T}_{4}$ - Deltametrin 2.8 & $\mathrm{C} @ 0.4 \mathrm{ml} / \mathrm{k}$ & kg seed & & $\mathrm{T}_{8}$ - Delt & metrin 2. & EC @ 0.4 & $\mathrm{nl} / \mathrm{kg}$ seed & Bavistin & (carbendaz & im) $50 \% \mathrm{~V}$ & $P$ ( @ 2g/k & seed & & & \\
\hline
\end{tabular}


Table.1b Effect of polymer coating, chemical seed treatment and containers on seed germination percentage of sweet corn cv Madhuri

\begin{tabular}{|c|c|c|c|c|c|c|c|c|c|c|c|c|}
\hline \multirow[t]{2}{*}{ Treatments } & \multicolumn{3}{|c|}{ Fifth month } & \multicolumn{3}{|c|}{ Sixth month } & \multicolumn{3}{|c|}{ Seventh month } & \multicolumn{3}{|c|}{ Nine month } \\
\hline & $\mathrm{C}_{1}$ & $\mathbf{C}_{2}$ & Mean & $\mathrm{C}_{1}$ & $\mathbf{C}_{2}$ & Mean & $\mathbf{C}_{1}$ & $\mathrm{C}_{2}$ & Mean & $\mathrm{C}_{1}$ & $\mathbf{C}_{2}$ & Mean \\
\hline $\mathrm{T}_{1}$ & $\begin{array}{c}92.46 \\
(74.11)^{*}\end{array}$ & $\begin{array}{c}93.53 \\
(75.31)\end{array}$ & $\begin{array}{c}93.00 \\
(74.71)\end{array}$ & $\begin{array}{c}91.39 \\
(72.99)\end{array}$ & $\begin{array}{c}92.35 \\
(73.99)\end{array}$ & $\begin{array}{c}91.87 \\
(73.49)\end{array}$ & $\begin{array}{c}86.73 \\
(68.68)\end{array}$ & $\begin{array}{c}88.73 \\
(70.45)\end{array}$ & $\begin{array}{c}87.73 \\
(69.57)\end{array}$ & $\begin{array}{c}81.82 \\
(64.81)\end{array}$ & $\begin{array}{c}86.07 \\
(68.17)\end{array}$ & $\begin{array}{c}83.95 \\
(66.49)\end{array}$ \\
\hline $\mathbf{T}_{2}$ & $\begin{array}{c}93.08 \\
(74.79)\end{array}$ & $\begin{array}{c}94.17 \\
(76.07)\end{array}$ & $\begin{array}{c}93.62 \\
(75.43)\end{array}$ & $\begin{array}{l}92.10 \\
(73.76)\end{array}$ & $\begin{array}{c}93.12 \\
(74.88)\end{array}$ & $\begin{array}{c}92.61 \\
(74.32)\end{array}$ & $\begin{array}{c}88.43 \\
(70.22)\end{array}$ & $\begin{array}{c}89.47 \\
(71.13)\end{array}$ & $\begin{array}{c}88.95 \\
(70.67)\end{array}$ & $\begin{array}{c}83.54 \\
(66.12)\end{array}$ & $\begin{array}{c}86.47 \\
(68.46)\end{array}$ & $\begin{array}{c}85.00 \\
(67.29)\end{array}$ \\
\hline $\mathbf{T}_{3}$ & $\begin{array}{c}93.15 \\
(74.88)\end{array}$ & $\begin{array}{c}94.56 \\
(76.55)\end{array}$ & $\begin{array}{c}93.86 \\
(75.72)\end{array}$ & $\begin{array}{l}91.44 \\
(73.05)\end{array}$ & $\begin{array}{c}93.02 \\
(74.72)\end{array}$ & $\begin{array}{c}92.23 \\
(73.88)\end{array}$ & $\begin{array}{l}89.09 \\
(70.81)\end{array}$ & $\begin{array}{c}90.79 \\
(72.39)\end{array}$ & $\begin{array}{c}89.94 \\
(71.60)\end{array}$ & $\begin{array}{c}86.05 \\
(68.11)\end{array}$ & $\begin{array}{c}88.23 \\
(70.01)\end{array}$ & $\begin{array}{c}87.14 \\
(69.09)\end{array}$ \\
\hline $\mathbf{T}_{4}$ & $\begin{array}{c}92.94 \\
(74.63)\end{array}$ & $\begin{array}{c}94.04 \\
(75.91)\end{array}$ & $\begin{array}{c}93.49 \\
(\mathbf{7 5 . 2 7})\end{array}$ & $\begin{array}{c}92.02 \\
(73.64)\end{array}$ & $\begin{array}{c}92.79 \\
(74.50)\end{array}$ & $\begin{array}{c}92.41 \\
(74.07)\end{array}$ & $\begin{array}{c}87.33 \\
(69.19)\end{array}$ & $\begin{array}{c}89.15 \\
(70.97)\end{array}$ & $\begin{array}{c}88.24 \\
(70.08)\end{array}$ & $\begin{array}{c}82.76 \\
(65.50)\end{array}$ & $\begin{array}{c}86.43 \\
(68.46)\end{array}$ & $\begin{array}{c}84.60 \\
(66.98)\end{array}$ \\
\hline $\mathbf{T}_{5}$ & $\begin{array}{l}94.10 \\
(75.98)\end{array}$ & $\begin{array}{c}95.05 \\
(77.19)\end{array}$ & $\begin{array}{c}94.58 \\
(76.58)\end{array}$ & $\begin{array}{c}92.83 \\
(74.52)\end{array}$ & $\begin{array}{c}94.07 \\
(75.99)\end{array}$ & $\begin{array}{c}93.45 \\
(75.25)\end{array}$ & $\begin{array}{c}90.53 \\
(72.19)\end{array}$ & $\begin{array}{c}92.27 \\
(74.09)\end{array}$ & $\begin{array}{c}91.40 \\
(73.14)\end{array}$ & $\begin{array}{c}87.21 \\
(69.12)\end{array}$ & $\begin{array}{c}89.85 \\
(69.12)\end{array}$ & $\begin{array}{c}\mathbf{8 8 . 5 3} \\
(\mathbf{7 0 . 3 9})\end{array}$ \\
\hline $\mathbf{T}_{6}$ & $\begin{array}{c}93.55 \\
(75.32)\end{array}$ & $\begin{array}{c}94.38 \\
(76.34)\end{array}$ & $\begin{array}{c}93.97 \\
(75.83)\end{array}$ & $\begin{array}{c}92.36 \\
(74.00)\end{array}$ & $\begin{array}{c}93.24 \\
(75.02)\end{array}$ & $\begin{array}{l}92.80 \\
(74.51)\end{array}$ & $\begin{array}{l}89.36 \\
(71.07)\end{array}$ & $\begin{array}{c}90.09 \\
(71.77)\end{array}$ & $\begin{array}{c}89.73 \\
(71.42)\end{array}$ & $\begin{array}{c}84.89 \\
(67.18)\end{array}$ & $\begin{array}{c}87.19 \\
(69.16)\end{array}$ & $\begin{array}{c}86.04 \\
(68.17)\end{array}$ \\
\hline $\mathbf{T}_{7}$ & $\begin{array}{c}94.46 \\
(76.42)\end{array}$ & $\begin{array}{l}95.64 \\
(77.99)\end{array}$ & $\begin{array}{c}95.05 \\
(77.21)\end{array}$ & $\begin{array}{c}93.14 \\
(74.86)\end{array}$ & $\begin{array}{l}94.76 \\
(76.80)\end{array}$ & $\begin{array}{c}93.95 \\
(75.83)\end{array}$ & $\begin{array}{c}91.09 \\
(72.70)\end{array}$ & $\begin{array}{c}93.40 \\
(75.19)\end{array}$ & $\begin{array}{c}92.24 \\
(73.95)\end{array}$ & $\begin{array}{c}88.75 \\
(70.57)\end{array}$ & $\begin{array}{c}90.60 \\
(72.37)\end{array}$ & $\begin{array}{c}89.68 \\
(71.47)\end{array}$ \\
\hline $\mathbf{T}_{8}$ & $\begin{array}{c}94.04 \\
(75.92)\end{array}$ & $\begin{array}{c}94.79 \\
(76.87)\end{array}$ & $\begin{array}{c}94.41 \\
(76.39)\end{array}$ & $\begin{array}{c}93.02 \\
(74.74)\end{array}$ & $\begin{array}{l}94.36 \\
(76.33)\end{array}$ & $\begin{array}{c}93.69 \\
(75.54)\end{array}$ & $\begin{array}{c}90.15 \\
(71.77)\end{array}$ & $\begin{array}{c}91.54 \\
(73.21)\end{array}$ & $\begin{array}{c}90.85 \\
(72.49)\end{array}$ & $\begin{array}{c}86.67 \\
(68.71)\end{array}$ & $\begin{array}{c}89.00 \\
(70.84)\end{array}$ & $\begin{array}{c}87.83 \\
(69.77)\end{array}$ \\
\hline C=Mean & $\begin{array}{c}93.47 \\
(\mathbf{7 5 . 2 6})\end{array}$ & $\begin{array}{c}94.52 \\
(76.53)\end{array}$ & $\begin{array}{c}94.00 \\
(75.89)\end{array}$ & $\begin{array}{c}92.29 \\
(73.94)\end{array}$ & $\begin{array}{c}93.46 \\
(75.28)\end{array}$ & $\begin{array}{c}92.88 \\
(74.61)\end{array}$ & $\begin{array}{c}89.09 \\
(70.83)\end{array}$ & $\begin{array}{c}90.68 \\
(72.40)\end{array}$ & $\begin{array}{c}89.88 \\
(\mathbf{7 1 . 6 1 )}\end{array}$ & $\begin{array}{c}85.21 \\
(67.52)\end{array}$ & $\begin{array}{c}87.98 \\
(69.89)\end{array}$ & $\begin{array}{c}86.60 \\
(68.70)\end{array}$ \\
\hline & S.Em & & $(\mathbf{P}=\mathbf{0 . 0 1})$ & S.Em & & $P=0.01)$ & S.Em & & $\mathbf{P}=0.01)$ & S.Em \pm & & $P=0.01)$ \\
\hline Container (C) & 0.11 & & 0.42 & 0.22 & & 0.82 & 0.40 & & 1.50 & 0.45 & & .70 \\
\hline Treatments (T) & 0.22 & & 0.84 & 0.44 & & 1.65 & 0.80 & & 2.99 & 0.91 & & .39 \\
\hline \begin{tabular}{|c|c|} 
\\
\end{tabular} & 0.32 & & NS & 0.63 & & NS & 1.13 & & NS & 1.29 & & NS \\
\hline NS - Non significant; & Conta & $\operatorname{ers}(\mathrm{C}):($ & - Cloth bą & & 2-Polyther & & & & & & & \\
\hline Treatments $(\mathrm{T})$ & & & & & & & & & & & & \\
\hline $\mathrm{T}_{1}$-Control & & & $\mathrm{T}_{5^{-}} \mathrm{Pc}$ & mer seed cc & ing@10 & $\mathrm{kg}$ of seec & Bavistin (c & endazim) & \%WP@2 & seed & & \\
\hline $\mathrm{T}_{2}$ - Polymer seed coat & g@10 ml/ & of seed & $\mathrm{T}_{6}-\mathrm{Pc}$ & mer seed cc & ing @ 10 & $\mathrm{~kg}$ of seec & Deltametri & .8EC@ 0 & $\mathrm{nl} / \mathrm{kg}$ seed & & & \\
\hline $\begin{array}{l}\mathrm{T}_{3-} \text { Bavistin (carbend } \\
\text { seed }\end{array}$ & im) $50 \%$ & P @ 2g/k & $\begin{array}{l}\mathrm{T}_{7}-\mathrm{Pc} \\
+\mathrm{Bav}\end{array}$ & $\begin{array}{l}\text { mer seed ce } \\
\text { n (carbend }\end{array}$ & $\begin{array}{l}\text { ing @ } 10 \\
\text { im) } 50 \%\end{array}$ & $\begin{array}{l}\mathrm{kg} \text { of seec } \\
@ 2 \mathrm{~g} / \mathrm{kg}\end{array}$ & Deltametri & .8EC@0 & $\mathrm{nl} / \mathrm{kg}$ seed & & & \\
\hline $\mathrm{T}_{4}$ - Deltametrin 2.8EC & $0.4 \mathrm{ml} / \mathrm{kg}$ & & $\mathrm{T}_{8^{-}} \mathrm{D}$ & metrin 2.8 & @ $0.4 \mathrm{ml}$ & seed + B & tin (carben & zim) $50 \%$ & P @ 2g/kg & & & \\
\hline
\end{tabular}


Table.2a Effect of polymer coating, chemical seed treatment and containers on seedling vigour index of sweet corn cv. Madhuri

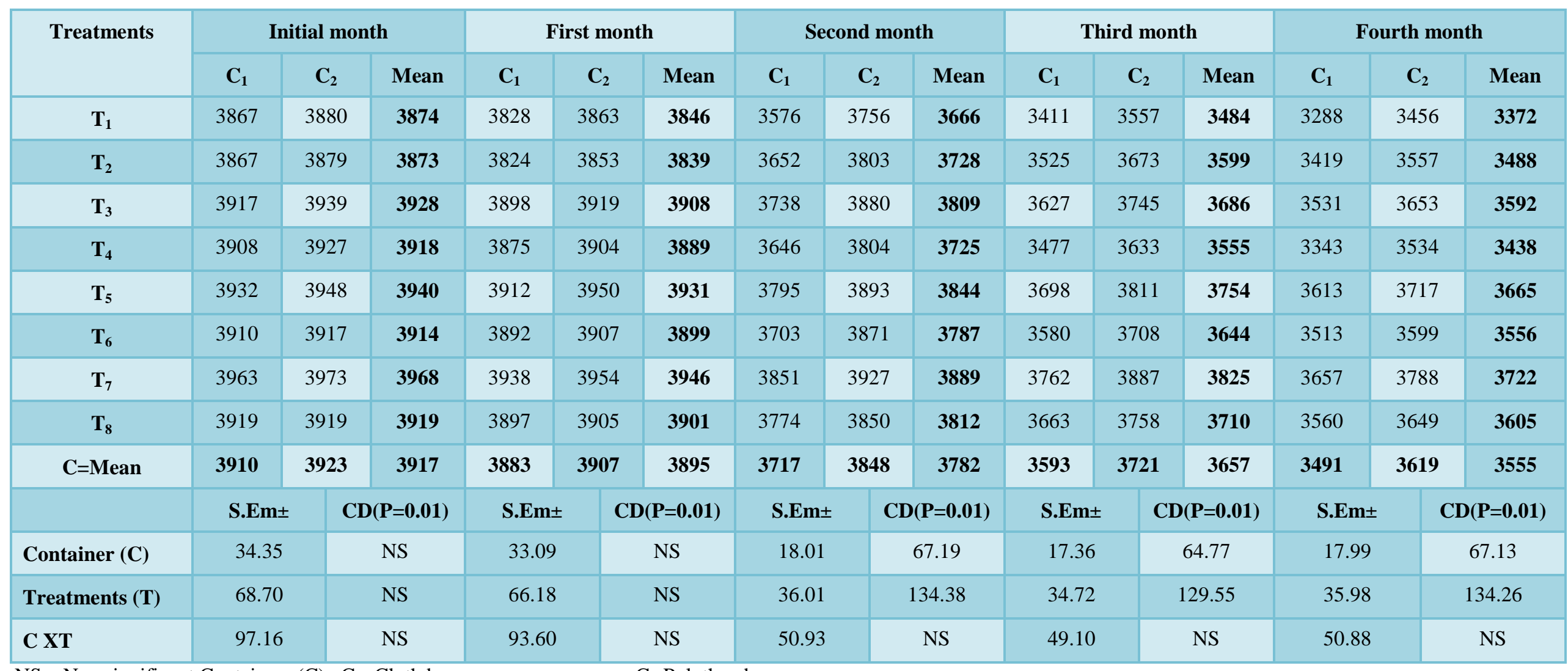

NS - Non significant Containers (C) : $\mathrm{C}_{1}$ - Cloth bag

$\mathrm{C}_{2}$-Polythen bag

\begin{tabular}{|c|c|}
\hline Treatments $(\mathrm{T})$ & \\
\hline $\mathrm{T}_{1}$-Control & $\mathrm{T}_{5^{-}}$Polymer seed coating @ $10 \mathrm{ml} / \mathrm{kg}$ of seed + Bavistin (carbendazim) 50\% WP @ 2g/kg seed \\
\hline $\mathrm{T}_{2}$ - Polymer seed coating @ $10 \mathrm{ml} / \mathrm{kg}$ of seed & $\mathrm{T}_{6}-$ Polymer seed coating @ $10 \mathrm{ml} / \mathrm{kg}$ of seed + Deltametrin 2.8EC @ 0.4ml $/ \mathrm{kg}$ seed \\
\hline $\begin{array}{l}\mathrm{T}_{3^{-}} \text {Bavistin (carbendazim) } 50 \% \text { WP @ } \\
2 \mathrm{~g} / \mathrm{kg} \text { seed }\end{array}$ & $\begin{array}{l}\mathrm{T}_{7} \text { - Polymer seed coating @ } 10 \mathrm{ml} / \mathrm{kg} \text { of seed + Deltametrin } 2.8 \mathrm{EC} @ 0.4 \mathrm{ml} / \mathrm{kg} \text { seed + Bavistin (carbendazim) } 50 \% \text { WP } \\
\text { @ } \mathrm{g} / \mathrm{kg} \text { seed }\end{array}$ \\
\hline $\mathrm{T}_{4}$ - Deltametrin 2.8EC @ 0.4ml $/ \mathrm{kg}$ seed & $\mathrm{T}_{8^{-}}$Deltametrin 2.8EC @ 0.4ml $/ \mathrm{kg}$ seed + Bavistin (carbendazim) 50\% WP @ 2g/kg seed \\
\hline
\end{tabular}


Table.2b Effect of polymer coating, chemical seed treatment and containers on seedling vigour index of sweet corn cv. Madhuri

\begin{tabular}{|c|c|c|c|c|c|c|c|c|c|c|c|c|}
\hline \multirow[t]{2}{*}{ Treatments } & \multicolumn{3}{|c|}{ Fifth month } & \multicolumn{3}{|c|}{ Sixth month } & \multicolumn{3}{|c|}{ Seventh month } & \multicolumn{3}{|c|}{ Nine month } \\
\hline & $\mathbf{C}_{1}$ & $\mathbf{C}_{2}$ & Mean & $\mathrm{C}_{1}$ & $\mathbf{C}_{2}$ & Mean & $\mathrm{C}_{1}$ & $\mathbf{C}_{2}$ & Mean & $\mathrm{C}_{1}$ & $\mathbf{C}_{2}$ & Mean \\
\hline $\mathbf{T}_{1}$ & 3179 & 3359 & 3269 & 2911 & 3197 & 3054 & 2820 & 3081 & 2951 & 2607 & 2862 & 2735 \\
\hline $\mathbf{T}_{2}$ & 3299 & 3438 & 3369 & 3082 & 3296 & 3189 & 2946 & 3207 & 3077 & 2785 & 3055 & 2920 \\
\hline $\mathbf{T}_{\mathbf{3}}$ & 3418 & 3548 & 3483 & 3221 & 3419 & 3320 & 3099 & 3304 & 3202 & 2957 & 3190 & 3073 \\
\hline $\mathbf{T}_{6}$ & 3378 & 3515 & 3446 & 3169 & 3355 & 3262 & 3027 & 3251 & 3139 & 2893 & 3116 & 3005 \\
\hline $\mathbf{T}_{7}$ & 3551 & 3696 & 3623 & 3404 & 3575 & 3489 & 3343 & 3495 & 3419 & 3131 & 3390 & 3261 \\
\hline $\mathbf{T}_{8}$ & 3447 & 3592 & 3520 & 3294 & 3451 & 3372 & 3180 & 3345 & 3262 & 2993 & 3230 & 3111 \\
\hline Treatments (T) & 42.8 & & 59.72 & 74. & & 77.62 & 72.3 & & 69.96 & 88.2 & & 29.30 \\
\hline C XT & 60.5 & & NS & 105 & & NS & 102. & & NS & 124.8 & & NS \\
\hline
\end{tabular}

NS - Non significant; $\quad$ Containers (C) $\quad: \mathrm{C}_{1}$ - Cloth bag $\quad \mathrm{C}_{2}$-Polythen bag

\begin{tabular}{|c|c|}
\hline Treatments $(\mathrm{T})$ & \\
\hline $\mathrm{T}_{1}$-Control & $\mathrm{T}_{5^{-}}$Polymer seed coating @ $10 \mathrm{ml} / \mathrm{kg}$ of seed + Bavistin (carbendazim) 50\% WP @ $2 \mathrm{~g} / \mathrm{kg}$ seed \\
\hline $\mathrm{T}_{2^{-}}$Polymer seed coating @ $10 \mathrm{ml} / \mathrm{kg}$ of seed & $\mathrm{T}_{6^{-}}$Polymer seed coating @ $10 \mathrm{ml} / \mathrm{kg}$ of seed + Deltametrin 2.8EC @ 0.4ml $/ \mathrm{kg}$ seed \\
\hline $\begin{array}{l}\mathrm{T}_{3^{-}} \text {Bavistin (carbendazim) 50\% WP @ } \\
2 \mathrm{~g} / \mathrm{kg} \text { seed }\end{array}$ & $\begin{array}{l}\mathrm{T}_{7-} \text { Polymer seed coating @ } 10 \mathrm{ml} / \mathrm{kg} \text { of seed + Deltametrin 2.8EC @ 0.4ml } / \mathrm{kg} \text { seed + Bavistin (carbendazim) } 50 \% \text { WP } \\
\text { @ 2g/kg seed }\end{array}$ \\
\hline $\mathrm{T}_{4}$ - Deltametrin 2.8EC @ 0.4ml $/ \mathrm{kg}$ seed & T $8^{-}$Deltametrin 2.8EC @ 0.4ml $/ \mathrm{kg}$ seed + Bavistin (carbendazim) 50\% WP @ 2g/kg seed \\
\hline
\end{tabular}


Table.3a Effect of polymer coating, chemical seed treatment and containers on seed infection (\%) of sweet corn cv. Madhuri

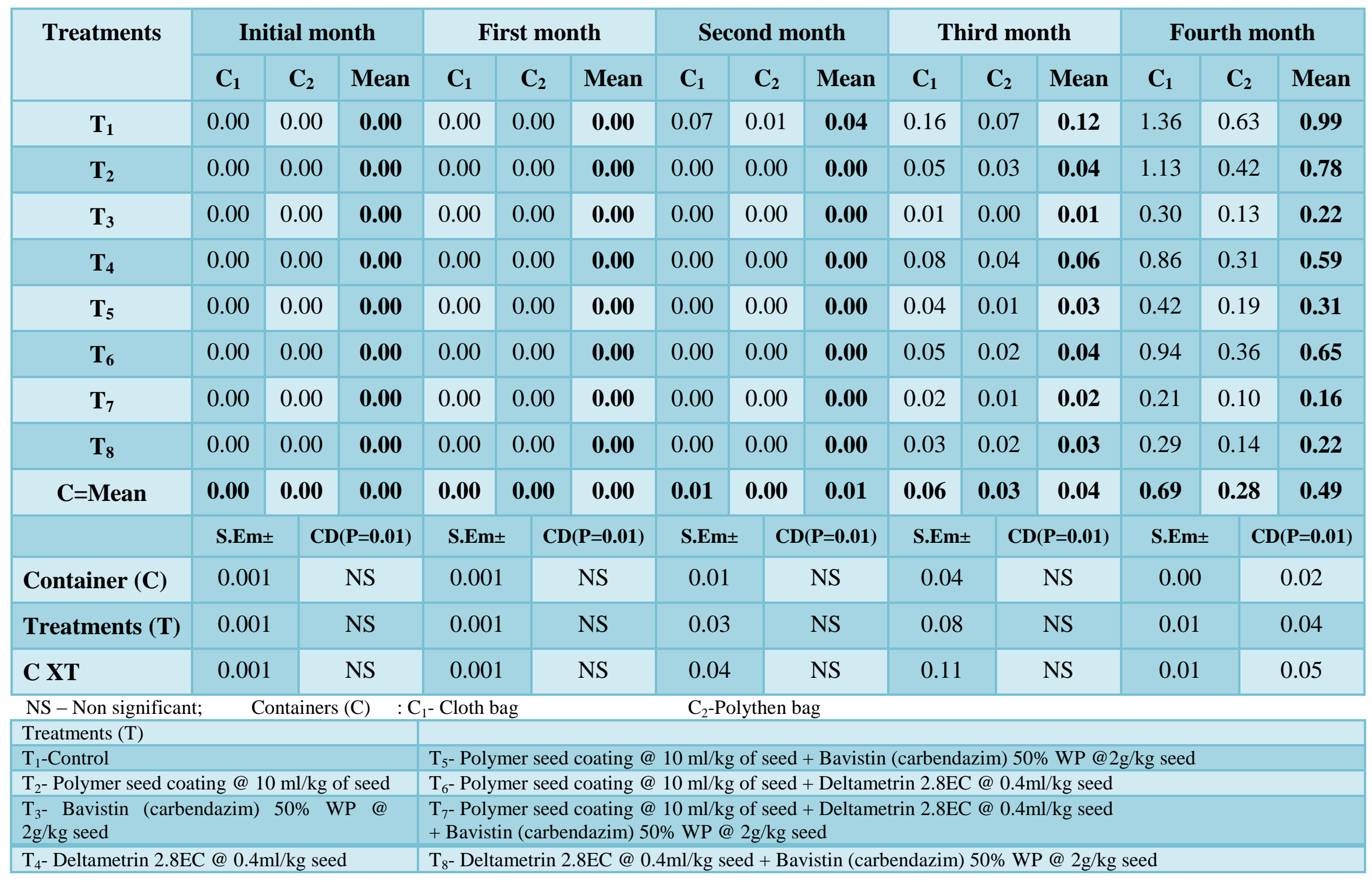


Table.3b Effect of polymer coating, chemical seed treatment and containers on seed infection (\%) of sweet corn cv. Madhuri

\begin{tabular}{|c|c|c|c|c|c|c|c|c|c|c|c|c|}
\hline \multirow[t]{2}{*}{ Treatments } & \multicolumn{3}{|c|}{ Fifth month } & \multicolumn{3}{|c|}{ Sixth month } & \multicolumn{3}{|c|}{ Seventh month } & \multicolumn{3}{|c|}{ Nine month } \\
\hline & $\mathbf{C}_{1}$ & $\mathrm{C}_{2}$ & Mean & $\mathbf{C}_{1}$ & $\mathrm{C}_{2}$ & Mean & $\mathbf{C}_{1}$ & $\mathbf{C}_{2}$ & Mean & $\mathbf{C}_{1}$ & $\mathbf{C}_{2}$ & Mean \\
\hline $\mathbf{T}_{1}$ & 1.94 & 0.78 & 1.36 & 2.64 & 1.12 & 1.88 & 3.42 & 1.53 & 2.48 & 4.21 & 1.89 & 3.05 \\
\hline $\mathbf{T}_{2}$ & 1.52 & 0.59 & 1.06 & 1.93 & 0.83 & 1.38 & 2.10 & 1.01 & 1.56 & 2.68 & 1.38 & 2.03 \\
\hline $\mathbf{T}_{3}$ & 0.46 & 0.21 & 0.34 & 0.69 & 0.34 & 0.52 & 0.93 & 0.46 & 0.70 & 1.31 & 0.68 & 1.00 \\
\hline $\mathbf{T}_{6}$ & 1.21 & 0.47 & 0.84 & 1.61 & 0.61 & 1.11 & 2.13 & 0.79 & 1.46 & 2.53 & 0.92 & 1.73 \\
\hline $\mathbf{T}_{7}$ & 0.49 & 0.24 & 0.37 & 0.82 & 0.42 & 0.62 & 1.28 & 0.67 & 0.98 & 1.49 & 0.93 & 1.21 \\
\hline $\mathbf{T}_{8}$ & 0.67 & 0.37 & 0.52 & 1.19 & 0.49 & 0.84 & 1.45 & 0.71 & 1.08 & 1.86 & 1.12 & 1.49 \\
\hline Treatments $(\mathbf{T})$ & \multicolumn{2}{|c|}{0.01} & 0.05 & \multicolumn{2}{|c|}{0.02} & 0.07 & \multicolumn{2}{|c|}{0.02} & 0.09 & \multicolumn{2}{|c|}{0.03} & 0.11 \\
\hline C XT & \multicolumn{2}{|c|}{0.02} & 0.07 & \multicolumn{2}{|c|}{0.03} & 0.10 & \multicolumn{2}{|c|}{0.03} & 0.12 & \multicolumn{2}{|c|}{0.04} & 0.15 \\
\hline
\end{tabular}

Treatments (T)

T $\mathrm{T}_{1}$-Control $\quad \mathrm{T}_{5^{-}}$Polymer seed coating @ $10 \mathrm{ml} / \mathrm{kg}$ of seed + Bavistin (carbendazim) $50 \% \mathrm{WP} @ 2 \mathrm{~g} / \mathrm{kg}$ seed

$\mathrm{T}_{2}$ - Polymer seed coating @ $10 \mathrm{ml} / \mathrm{kg}$ of seed $\mathrm{T}_{6}$ - Polymer seed coating @ $10 \mathrm{ml} / \mathrm{kg}$ of seed + Deltametrin 2.8EC @ 0.4ml $/ \mathrm{kg}$ seed

T $3^{-}$Bavistin (carbendazim) 50\% WP @ $\quad \mathrm{T}_{7^{-}}$Polymer seed coating @ $10 \mathrm{ml} / \mathrm{kg}$ of seed + Deltametrin 2.8EC @ 0.4ml $/ \mathrm{kg}$ seed

$2 \mathrm{~g} / \mathrm{kg}$ seed

+ Bavistin (carbendazim) 50\% WP @ 2g/kg seed

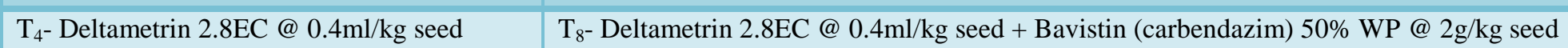


Whereas, the $\mathrm{C}_{2} \mathrm{~T}_{5}$ (seeds treated with polymer seed coating @ $10 \mathrm{ml} / \mathrm{kg}$ of seed and stored in polythene bag) recorded EC of $\left(0.211 \mathrm{dSm}^{-1}\right)$ after the fourth month of storage. Similar trend of electrical conductivity among the containers and treatments were recorded in entire storage period. These results are in conformity with the findings of Suresh and Renganayaki (2008) in maize seeds.

Significant difference was observed in interaction effects of storage containers and seed treatments from fourth month of storage up to nine months in seed infection. Among the interactions, significantly highest seed infection was recorded in $\mathrm{C}_{1} \mathrm{~T}_{1}(1.36 \%)$ (Untreated seeds stored in cloth bag) followed by $\mathrm{C}_{1} \mathrm{~T}_{2}$ (polymer seed coating @ $10 \mathrm{ml} / \mathrm{kg}$ of seed and stored in cloth bag 1.13\%) and lowest seed infection was seen in $\mathrm{C}_{2} \mathrm{~T}_{7}$ (polymer seed coating @ $10 \mathrm{ml} / \mathrm{kg}$ of seed in combination of deltametrin 2.8EC @ $0.4 \mathrm{ml} / \mathrm{kg}$ seed and bavistin (carbendazim) $50 \%$ WP @ 2g/kg treated seed and stored in polythene bag $0.10 \%$ ) and the same trend was continued up to the end of storage period. At the end of nine months of storage, significantly highest seed infection was recorded in $\mathrm{C}_{1} \mathrm{~T}_{1}(4.21 \%)$ followed by $\mathrm{C}_{1} \mathrm{~T}_{2}$ $(2.68 \%)$ and was minimum with $\mathrm{C}_{2} \mathrm{~T}_{7}(0.93$ $\%)$. The seeds stored in polythene bag helped in maintaining the seed quality at higher level due to less degradation of seed reserve and minimum influence of extrinsic factors. These results are in conformity with the findings of Suresh and Renganayaki (2008) in maize and Raikar et al., (2011) in rice.

Insect infestation in sweet corn as influenced by the interaction effects of seed treatments and containers showed significant differences from second month of storage up to the end of storage period. Significantly highest seed infection was recorded in $\mathrm{C}_{1} \mathrm{~T}_{1}$ (Untreated seeds stored in cloth bag, $0.31 \%$ seed infection) and no insect damage was seen in other interaction after second month of storage. At the end of nine months of storage significantly highest seed infection was recorded in (7.94\%) $\mathrm{C}_{1} \mathrm{~T}_{1}$ (untreated seeds stored in cloth bag) followed by $\mathrm{C}_{1} \mathrm{~T}_{3}$ (bavistin (carbendazim) 50\% WP @ 2g/kg seed and stored in cloth bag, 5.23\%) and was minimum with $\mathrm{C}_{2} \mathrm{~T}_{4}$ (deltametrin 2.8EC @ $0.4 \mathrm{ml} / \mathrm{kg}$ seed and stored in polythene bag, $0.43 \%$ ). These results are in conformity with the findings of Suresh and Renganayaki (2008) in maize seeds.

From the present investigation it is concluded that sweet corn seeds stored in polythene bag maintained better seed quality parameters throughout the storage period as compared to the seeds stored in cloth bag under ambient condition. Seed coating with polymer seed coating@10 ml/kg of seed in combination with deltametrin 2.8EC @ $0.4 \mathrm{ml} / \mathrm{kg}$ seed and bavistin (carbendazim) 50\% WP @ 2g/kg seed helped to maintain higher seed quality as compared to the coating with polymer alone for more than nine months.

\section{References}

Hunje, R. V., 2002. Studies on seed production and post-harvest techniques in chilli (Capsicum annuum L.). Ph.D. Thesis, Univ. Agric. Sci., Dharwad, Karnataka (India).

Hunje, R. V., Kulkarni, G. N., Shashidhar, S. D. and Vyakaranahal, B. S., 1990. Effect of insecticide and fungicide treatment on cowpea seed quality. Seed Res., 18: 90-92.

Hussaini, S. H., Zaheda, A. A. and Dhanraj, A., 1988. Effect of accelerated ageing on germination, vigour and yield of maize. Seed Res., 16: 68-75.

Imran Baig, Biradar Patil, N. K., Ninganur, B. T., Patil, R. H. and Ravi Hunje., 2005. Effect of grading methods, fungicides 
and polymer coating on storability of Soybean (Glycine max (L.) Merrill). M.Sc. (Agri) Thesis, Univ. Agril. Sci., Dharwad, Karnataka (India).

Manojkumar and Agarwal, V. K., 1998. Effect of fungicidal seed treatment on seed fungi, germination and seedling vigour in maize. Seed Res., 26(2): 147151.

Martin, J. A., Senn, T. L., Skelton, B. J. and Crowford, J. H., 1960. Response of okra seed to moisture content and storage temperature. In: Proceedings of the American Soc. for Hort. Sci., 75: 490 494.

Merwade, M. N., 2000. Investigation on seed production techniques and storability of chickpea. Ph.D. (Agri.) Thesis, Univ. Agril. Sci., Dharwad, Karnataka (India).

Monira, U.S., Amin, M. H. A., Aktar, M. M. and M.A.A. Mamun, M. A.A., 2012. Effect of Containers on Seed Quality of Storage Soybean Seed. Bangladesh Res. Pub. J., 7(4): 421-427. Retrieve from http://www.bdresearchpublications.com /admin/journal/upload/09364/09364.pdf

Patil, S. K., Janpure, S. V., Shelar, V. R. and Dumbre, A.D., 2004. Efficacy of insecticides and fungicides on seed germination, insect infestation and seed mycoflora on pearlmillet during storage. Seed Res., 32(2): 189-192.

Paul, M. E. and Mishra, R. R., 1994. Seed germination and seedling vigour of maize as influenced by different fungicides. Crop Res., 7: 454-460

Paul, S. R., Sharma, N. N., Sarma, D., Borah, R. K. and Nath, P. D., 1996. Maintenance of viability and vigour of stored mungbean seeds under the ambient conditions in the hill zones of Assam. Annals Agric. Res., 17(2): 196198.

Poonam Singh, Maurya, C. L., Gaura, Kumakumar and Bajpai, V. P., 2004. Effect of biological and chemical fungicide on longevity of rice hybrid (DRRH-1) and its parental lines seeds. Seed Res., 32(2): 177-179.

Raikar, S. D., Vyakarnahal, B. S., Biradar, D. P., Deshpande, V. K. and Janagoudar, B. S., 2011. Effect of seed source, containers and seed treatment with chemical and boipesticide on storability of scented rice cv. Mugad sughanda. Karnataka J. Agric. Sci., 24(4): 448454.

Ravishankar, R. V., Lokesh, S. and Khan, A., 2002. Occurrence and management of some seed borne fungi pathogens of maize and sorghum in vitro. Seed Res., 30(1):112-117.

Riudavets, J., Salas. I. and Pons, M. J., 2007. Damage characteristics produced by pest in packaging film. J. Storage Processing Res., 43: 564-570.

Roberts, E. H. and Abdalla, F. H., 1986. The influence of temperature moisture and oxygen on period of seed viability in barley, broad bean and peas. Annals Bot., 32: 91-117.

Savitri, H., Sugankar Reddy, M. and Muralimohan Reddy, 1998. Effect of seed treatment with fungicides and insecticides on seed borne fungi, storage pest, seed viability and seedling vigour in groundnut. Seed Res., 26(1): 62-72.

Savitri, H., Sugunakar Reddy, M. and Muralimohan Reddy, B., 1994. Effect of seed treatment with fungicides and insecticides on seed borne fungi, storage insect pest and seed viability and seedling vigour of sorghum. Seed Res., 22(2): $146-155$.

Schwinn, F., 1994. Seed treatment - a panacea for plant protection? Seed Treatment: Progress and Prospects. BCPC Publications. Monograph 57, 3. Retrieved: September 9, 2014 from http://www.amazon.com/gp/ search.

Shakuntala, N. M., 2009. Influence of planting ratios, staggered planting and 
seed polymer coating on seed yield, quality and storability in RSFH-130 sunflower hybrid, Ph.D. Thesis, Univ. Agric. Sci., Dharwad, Karnataka (India).

Snedecor, G. W. and Cochiran, W. G., 1967. Statistical methods, oxford and $\mathrm{BH}$ Pub. Co., Bombay, pp. 135-139.

Sundarajan, N., Nagraju, S., Venktataraman, S. and Jaganath, M. H., 1972. Design and Analysis of Field Experiments. Univ. Agri. Sci., Bangalore. pp. 167195.

Sunilkumar, Nagangouda, A. and Patil, B. V., 2005. Evaluation of botanicals powders against rice weevil (Sitophilus oryzae) in stored sorghum. Karnataka J. Agric. Sci., 18(4):1117-1120.

Suresh, V. and Renganayaki, P. R., 2008. Standardization of polymer coating technology for mechanization in maize hybrid $\mathrm{COH}$ (M) 5. Seed Res., 29(2): 147-151

Sushma, D. M., 2003. Effect of seed treatment and containers on seed storability of garden pea (Pisum sativum L.). M.Sc. (Agri) Thesis, Univ. Agric. Sci., Dharwad, Karnataka (India).

Sushma, P. P, 2013. Effect of polymercoat and seed treatment chemicals on seed storability and field performance of chickpea. M.Sc. (Agri) Thesis, Univ.
Agril. Sci., Dharwad, Karnataka (India). Tanweer, A., 1982, Effect of new fungicide on viability of rice and sorghum seeds. Pestology, 6:9-10.

Vanangamudi, K., Srimathi, P., Natarajan, N. and Bhaskaran, M., 2003. Current scenario of seed coating polymer. ICAR - Short Course on Seed Hardening and Pelleting Technol. for Rain Fed or Garden Land Ecosystems, pp: 80-100.

Vasundhara, S. and Bommegouda, A., 1999. Effect of fungicidal seed treatment on seed quality of groundnut seeds in storage. Seed Res., 27(2): 223-224.

Vijay Kumar, K., Ravi Hunje, Biradar Patil, N. K., Vyakarnhal, B. S., 2007. Effect of seed coating with polymer, fungicide and insecticide on seed quality in cotton during storage. Karnataka J. Agric. sci., 20(1): 137-139

Vinodkumar, S. B., Vyakaranahal, B. S., Dhananjaya, P., Yegappa Hipparagi, Asha, A. M., 2012. Effect of seed polymer coating on field performance and quality of Pigeonpea [Cajanus cajan (L.) Millsp]. Eng. \& Ecology., 31(1): 43-46.

Zink, E. and DcMendoca, N. T., 1965. The effect of the extraction method of viability of pumpkin seeds. Bragantia, 24: $1-2$.

\section{How to cite this article:}

Jolli, R. B., V. H. Nayak, M. B. Boranayaka and Latha, H. C. 2020. Effect of Polymer Coat, Seed Treatment Chemicals and Containers on Seed Germination, Vigour Index, Infestation and Other Quality Traits in Sweet Corn during Seed Storage. Int.J.Curr.Microbiol.App.Sci. 9(06): 3090-3105. doi: https://doi.org/10.20546/ijcmas.2020.906.370 